\title{
DESAIN PEMBELAJARAN FLIPPED LEARNING SEBAGAI SOLUSI MODEL PEMBELAJARAN PAI ABAD 21
}

\author{
Abdulloh Hamid \\ UIN Sunan Ampel, Surabaya, Indonesia \\ doelhamid@uinsby.ac.id \\ Mohamad Samsul Hadi \\ UIN Sunan Ampel, Surabaya, Indonesia \\ el.hadee98@gmail.com
}

\begin{abstract}
Abstrak
Penelitian ini bertujuan untuk mendeskripsikan desain pembelajaran terbalik atau flipped learning dan penerapannya sebagai salah satu bentuk pembelajaran berbasis teknologi dalam meningkatkan kompetensi Teknologi Informasi dan Komunikasi (TIK) guru, utamanya guru agama di sekolah maupun madrasah. Metode penelitian yang digunakan adalah metode analisis deskriptif dengan teknik pengumpulan data terkait desain pembelajaran flipped learning yang telah banyak diterapkan. Hasil yang diperoleh menunjukkan bahwa desain pembelajaran flipped learning dapat meningkatkan keterlibatan peserta didik dalam proses pembelajaran, serta menjadikan waktu penyampaian materi lebih efisien. Meskipun tetap ditemukan kendala seperti keterbatasan alat teknologi, serta yang paling menghambat adalah tidak adanya kompetensi TIK bagi guru. Kesimpulan dari penelitian ini adalah desain pembelajaran flipped learning cukup efektif untuk meningkatkan keaktifan peserta didik dibanding metode pembelajaran konvensional.
\end{abstract}

Kata Kunci : flipped learning, teknologi informasi komunikasi, guru agama, konvensional

\begin{abstract}
This study aims to describe the design of reverse learning or flipped learning and its application as a form of technology-based learning in improving the competence of information and communication technology (ICT) teachers, mainly religious teachers in schools and madrasa. The research method used is a descriptive analysis method with data collection techniques related to a flipped learning design that has been widely applied. The results it shows are that flipped learning design learning can increase learners involvement in the learning process, and make time for material delivery more efficient. Although the constraints are still found such as limited technological equipment, and the most impede is the absence of ICT competence for teachers. The conclusion of this research is that the flipped learning design is effective enough to increase the activity of learners over conventional learning methods.
\end{abstract}

Keywords : flipped learning, ICT, religious teachers, conventional 


\section{A. Pendahuluan}

Secara konvensional, pembelajaran dilaksanakan dengan tatap muka antara guru dengan murid atau dosen dengan mahasiswa dalam masingmasing kelas. Selepas pertemuan, terkadang siswa maupun mahasiswa dibebani tugas sebagai bentuk evaluasi pembelajaran di kelas. Akan tetapi dalam pelaksanaannya, pembelajaran dengan model tradisional tersebut tidak banyak berdampak terhadap keaktifan peserta didik. Pembelajaran terkesan mereduksi bahan materi dan ajar. Guru dengan berbagai perbedaan teknik mengajarnya dituntut memenuhi jam belajarnya. Harapannya, peserta didik mampu menguasai segala materi yang diberikan. Namun terkadang beberapa dari mereka belum bisa menerima itu semua.

Maka dari itu, di era teknologi yang luar biasa ini, para pakar keilmuan mencoba mengatasi problematika peserta didik dalam menerima materi yang diajarkan. Bagaimana caranya agar pembelajaran dapat efektif dan adaptif dengan perubahan dan perkembangan teknologi yang kini dihadapi para peserta didik. Setelah melakukan eksperimen serta observasi terhadap efektivitas pembelajaran berikut guru dan peserta didiknya, muncul berbagai konsep pembelajaran yang dianggap cukup relevan dengan kemajuan teknologi tersebut, salah satunya yaitu blended learning yang merupakan kombinasi pertemuan pendidik-peserta didik dalam kelas dengan pembelajaran dalam jaringan (online) di luar kelas.

Dari konsep blended learning ini, model pembelajaran mulai berkembang. Diantaranya adalah flipped learning. Model pembelajaran ini memberikan inovasi terhadap paradigma pembelajaran di dalam kelas. Sebelumnya pada lingkup perkuliahan para dosen berdiri di suatu kelas dengan menjelaskan materi perkuliahan satu persatu, sementara peserta didik atau mahasiswanya mencatat penjelasan materi yang diberikan tersebut. Kemudian pada akhir perkuliahan mereka dibebani tugas sebagai pekerjaan rumah yang mengharuskan mereka berburu ma'a>khid berupa literatur atau berbagai sumber lainnya sebagai bahan pokok tugas dan untuk menjawab satu persatu pertanyaan dosen. Aktivitas tersebut berjalan sesuai dengan jadwal 
yang ditentukan dan dosen menyadari bahwa banyak materi yang harus dituntaskan di setiap tatap muka hingga akhir semester. Model pembelajaran tradisional semacam ini dapat lebih efisien dengan adanya model flipped learning. (Yulhendri, 2019:2)

Pada umumnya, beberapa lembaga pendidikan masih menggunakan metode ceramah berupa penjelasan materi secara langsung oleh seorang guru di kelas pada setiap sesi pembelajaran dalam satu waktu saja. Dalam kondisi seperti ini, peserta didik yang ingin mendalami materi tersebut atau bahkan yang belum memahaminya tentu akan kesulitan untuk mengulang kembali. Sebab guru tidak mungkin menjelaskan materi yang sama dalam pertemuan yang berbeda. Hal ini tentu menjadi kendala tersendiri dalam proses penyampaian materi.

Kenyataannya beberapa metode konvensional seperti ceramah tersebut masih banyak digunakan di berbagai lembaga pendidikan Islam. Materi PAI yang diajarkan seolah hanya berkutat pada penyampaian secara lisan; statis tidak berkembang dan terpaku pada teks kitab saja. Guru agama sebagai penampu cukup berasumsi bahwa metode ini cukup mudah diterapkan, siswa dianggap mudah menerima. Padahal tidak semuanya demikian. Adakalanya fleksibilitas diperlukan dalam belajar hingga tercipta suasana menyenangkan.

Pembelajaran PAI sebagaimana pelajaran lain berhak didesain sekreatif mungkin dalam proses pencapaian belajar. Materi yang diajarkan dapat disesuaikan dengan kebutuhan demi terciptanya pembelajaran yang variatif dan dinamis. Salah satunya melalui konsep blended learning pada model flipped learning ini. Upaya ini sekaligus membuktikan bahwa pendidikan Islam tidak dapat terlepas dari pengaruh teknologi.

Penelitian ini menggunakan metode analisis deskriptif kualitatif dengan teknik pengumpulan, pengolahan dan analisa data terkait desain pembelajaran flipped learning sebagai salah satu desain pembelajaran modern PAI abad 21. Dalam penelitian ini, peneliti menggunakan desain penelitian library research atau penelitian pustaka, sebab data yang diperoleh berasal dari artikel ilmiah dan penelitian terdahulu yang telah terpublikasi. Sebagaimana 
yang dikatakan Zed (2004:3) bahwa penelitian pustaka ini adalah serangkaian kegiatan yang berkaitan dengan metode pengumpulan data pustaka, membaca, mencatat serta mengolah bahan penelitian.

Melalui penelitian pustaka ini, peneliti berupaya menghimpun data yang bersumber dari artikel-artikel tersebut dan menganalisanya sehingga menjadi satu fokus penelitian yang dikaji, yaitu desain pembelajaran flipped learning. Metode pengumpulan data yang digunakan adalah dengan studi dokumen terkait desain pembelajaran flipped learning yang kemudian dilanjutkan dengan proses analisa data sesuai dengan tujuan penelitian. Instrumen pengumpulan data yang digunakan adalah dengan teknik observasi nonparticipatory. Peneliti mengamati efektifitas model pembelajaran konvensional yang telah berjalan hampir di semua sekolah atau madrasah dengan model pembelajaran flipped learning yang cukup diminati di abad 21 ini.

\section{B. Pembahasan}

Penelitian ini mendeskripsikan desain pembelajaran flipped learning sebagai solusi model pembelajaran PAI di abad 21. Berdasarkan hasil penelitian, peneliti dapat menyimpulkan bahwa : (1) model pembelajaran flipped learning menjadikan peserta didik lebih banyak aktif dan terlibat dalam proses belajar-mengajar, hal ini karena flipped learning besifat studentcentered dibanding metode konvensional pada umumnya; (2) sebagaimana materi pelajaran pada umumnya, PAI juga dapat disesuaikan dengan keterampilan guru dalam mendesain pembelajaran semenarik mungkin, dan (3) meskipun alat teknologi telah memadai, proses flipped learning tidak akan efektif jika guru belum memiliki kompetensi TIK atau ICT. Karena hal itu merupakan syarat mutlak dalam penerapan flipped learning ini.

Menurut McKnight (2013:4), Flipped Learning merupakan suatu model pembelajaran yang menuntut guru mengalihkan pembelajaran langsung dari ruang belajar berskala besar (ruang kelas) ke dalam ruang belajar 
individual dengan bantuan beberapa alat teknologi. Model ini merupakan salah satu model pembelajaran kekinian yang masih satu turunan konsep Elearning. Pada model flipped learning ini, guru maupun dosen bertugas membuat materi-materi dalam bentuk tulisan, narasi, video, podcast dan berbagai media lainnya yang mampu dijangkau peserta didiknya di luar ruangan kelas.

Dalam model pembelajaran flipped learning ini, hal-hal yang biasa dilakukan di ruang kelas seperti penjelasan materi, pemberian tugas, latihan soal serta tugas rumah dipindahkan atau dibalik ke dalam pembelajaran berbasis online. Bahan ajar guru maupun dosen yang berupa video, form online, tulisan yang telah dibuat nantinya akan dipelajari peserta didik di rumah. Sebelum memasuki kelas mereka diupayakan telah mengantongi sejumlah informasi yang berasal dari konten-konten materi tersebut. Selanjutnya ketika berada di kelas, mereka aktif melakukan studi kasus, uji lab, praktikum, permainan, simulasi dan eksperimen. Tugas-tugas seperti essai dan pemecahan masalah lebih baik dilaksanakan di kelas, sedangkan mendengar dan melihat materi ajar yang diberikan guru ataupun dosen lebih bagus dilakukan di rumah dalam bentuk video. Dari sinilah dikenal istilah flipped learning (Herreid \& Schiller, 2014 : 62). Selanjutnya dapat dikatakan bahwa model pembelajaran flipped learning ini merupakan perpaduan antara pembelajaran tradisional yang mengharuskan adanya pertemuan antara guru maupun dosen dengan peserta didiknya di kelas dengan pembelajaran berbasis online (Blended Learning). Maka pembelajaran di dalam kelas cenderung lebih bersifat student-centered dibanding model pembelajaran lainnya. Peserta didik berperan lebih aktif dari gurunya. Sebab, dalam kasus ini guru hanya memotivasi, membimbing dan memberi umpan balik atas kinerja peserta didiknya (Sams \& Bergmann, $2012: 87$ ).

Model flipped learning ini juga memberikan kemudahan bagi para peserta didik untuk mengakses segala sumber pengetahuan dimanapun berada. Jika sebelumnya para peserta didik dituntut mencari referensi berupa buku, literatur dan media cetak lainnya yang tidak mudah dijangkau, maka pada 
model pembelajaran terbalik ini semua referensi tersebut dapat diakses dalam satu atau lebih suatu alat teknologi.

Bentuk kemudahan tersebut pada akhirnya menjadi suatu motivasi belajar peserta didik dalam menerima materi dan pelajaran dari gurunya. Melalui model flipped learning ini, peserta didik tidak lagi bosan dan jenuh mendengarkan ceramah gurunya. Mereka lebih mempunyai banyak waktu untuk mencari solusi suatu masalah, baik secara individual maupun kolaboratif dengan berdiskusi. Dengan demikian, model flipped learning ini secara tidak langsung memanfaatkan aktivitas peserta didik di luar kelas dengan pendekatan pedagogis serta lebih mengurangi waktu bermain-main mereka di rumah.

Gagasan awal model flipped learning ini sebenarnya telah ada sejak tahun 1993. Hal itu dibuktikan dengan pendapat Alison King dalam tulisannya : From Sage on the Stage to Guide on the Side. Meskipun secara tidak langsung menyinggung istilah flipped learning, namun ia mengatakan bahwa waktu tatap muka guru dan siswa guna memperoleh pengetahuan dan pemahaman jauh lebih berharga daripada hanya sekedar transmisi keilmuan (Edukasi, 2019). Ia juga mengungkapkan bahwa pembelajaran tradisional yang digambarkan dengan seorang profesor mentransfer keilmuan kepada mahasiswanya tidak akan efektif digunakan dalam pembelajaran abad 21. Sebab hal itu menjadikan mahasiswa cenderung pasif. Mereka seolah tidak mampu berpikir sendiri. Dan yang lebih parah lagi, ia berpendapat bahwa dalam kondisi tersebut otak mereka seolah wadah kosong yang dituang dengan pemikiran profesornya (Alison King, $2010: 30$ ).

Di tahun 1997, gelisah Alison King mulai dirasakan Eric Mazur, seorang profesor di Harvard University. Ia mulai mengadopsi pemikiran King dengan mengubah model pembelajaran yang serupa, yaitu dengan memadukan transmisi keilmuan siswanya di luar dan di dalam kelas agar tercapai tujuan pendidikan mereka.

Selang beberapa tahun kemudian, tepatnya tahun 2000, tiga cendekiawan, Lage, Platt dan Treglia mempublikasikan artikel penelitian kali 
pertama pada model pembelajaran kelas terbalik yang menuai reaksi positif dari murid-murid mereka. Begitu juga yang terjadi di tahun 2004, Salman Khan membuat pembelajaran matematika dalam video berdurasi pendek yang kemudian ia unggah ke situsnya, Khan Academy (Roehling, $2018: 3$ ).

Kemudian di tahun 2007, gagasan model pembelajaran flipped learning yang sebelumnya telah berjalan mulai dikembangkan oleh Jonathan Bergmann dan Aaron Sams, dua guru kimia di Woodland Park High School, Colorado. Kala itu, mereka mengkhawatirkan para siswanya yang sering melewatkan pelajaran kimia karena berbagai alasan seperti kompetisi, pertandingan, even dan sebagainya. Setelah itu keduanya mulai berpikir untuk memanfaatkan teknologi yang ada. Kemudian mereka memutuskan merekam video pembelajaran di kelasnya mulai dari ceramah, demonstrasi dan slide presentasi sebagai langkah antisipatif. Rekaman tersebut kemudian mereka unggah ke YouTube yang baru saja dibuat untuk siswa agar diunduh dan diakses kapanpun dan dimanapun. Pada 2012, mereka berdua mendirikan organisasi (Flipped Learning Network) untuk membekali para pendidik dengan keterampilan, pengetahuan dan berbagai bahan ajar untuk mengimplementasikan flipped learning (Hamdan et al., $2013: 3$ )

Dapat dikatakan, model flipped learning merupakan salah satu inovasi pembelajaran yang cukup mengandalkan berbagai materi yang diunggah di media online dengan menuntut kemandirian berpikir peserta didik melalui diskusi, pemecahan masalah, kerja kelompok, studi kasus dan lain sebagainya yang dilakukan di ruangan kelas sebagai hasil belajarnya di rumah. Model pembelajaran ini lebih bersifat student-centered yang mendorong keaktifan peserta didik di kelas, dan guru maupun dosen hanya membimbing serta memotivasi saja.

Sebagaimana yang telah diuraikan sebelumnya, model flipped learning ini memadukan konsep pembelajaran konvensional (tatap muka guru dengan peserta didik dalam ruangan kelas) dengan pembelajaran daring (online). Menurut Graham Bents (2013 : 2), model flipped learning ini merupakan strategi instruksional yang diterapkan di berbagai sekolah yang bertujuan 
meminimalisasi sejumlah instruksi secara langsung dalam proses belajar mengajar.

Strategi ini juga efektif mengurangi waktu belajar di kelas yang umumnya menggunakan metode-metode klasik seperti ceramah yang ada di sekolah islam atau madrasah. Sebagaimana yang telah diketahui, pelajaranpelajaran agama cenderung bersifat klasik dan teacher-centered yang lebih mudah disampaikan dalam bentuk ceramah. Namun dengan metode ini peserta didik menjadi lebih bergantung pada keaktifan guru yang mengakibatkan mereka kurang mandiri dan tidak ada persiapan belajar. Hal ini sangat berpengaruh pada daya pikir mereka dalam menganalisa materi yang didapatkan. Maka penerapan flipped learning dapat berjalan dengan baik jika karakteristik pelajaran agama diubah menjadi student-centered melalui instruksi para guru. Sebagai contoh, pelajaran akidah dapat dititik-pusatkan kepada analisa peserta didik melalui kisah-kisah para nabi dalam bentuk video animasi atau film. Setelah melihat video kisah tersebut, mereka merangkum materi yang diperoleh dan selanjutnya dapat didiskusikan dalam ruang kelas secara kolaboratif. Dari sini dapat dikatakan bahwa semua materi pelajaran, termasuk materi PAI dapat disesuaikan dengan strategi dan inovasi yang ditawarkan guru.

Strategi model flipped learning dinilai lebih masuk akal dan kompatibel di masa teknologi seperti sekarang ini, khususnya pada pelajaran agama yang cenderung tradisional. Materi-materinya tidak hanya dijumpai secara tertulis di kitab, tetapi juga dapat digali melalui video dan media lainnya. Hal tersebut tidak dapat dipungkiri, sebab konsep awal penerapan pembelajaran terbalik itu sendiri muncul karena adanya perbedaan yang terjadi pada peserta didik. Beberapa dari mereka memiliki orangtua berpendidikan yang mampu membantu tugas mereka, sementara yang lain tidak. Pada kasus demikian, mereka hanya mengandalkan bantuan dari para ahli di lapangan (pendidik di sekolah). Maka strategi flipped learning tersebut memberikan dukungan kepada peserta didik untuk menyelesaikan tugas mereka. Strategi 
tersebut menyediakan waktu kepada mereka untuk menganalisis konten yang telah diberikan (Schmidt \& Ralph, $2015: 1$ ).

Namun mengingat strategi ini bersinggungan langsung dengan teknologi, tentunya ia memiliki keterbatasan. Diantaranya adalah kemungkinan timbulnya pembelajaran yang tidak efektif. Hal ini dapat terjadi sebab peserta didik menggunakan alat-alat mereka sendiri. Sebagai contoh mereka mengakses video pembelajaran sembari melihat siaran sepak bola atau mendengarkan musik. Hal tersebut tentu mengurangi perhatian mereka terhadap konten materi yang telah diberikan. Namun keterbatasan tersebut dapat diatasi dengan adanya pengawasan dan pendampingan intensif orang tua ataupun orang terdekat peserta didik.

Pemberdayaan strategi model flipped learning menjadi efektif pada setiap tingkat pendidikan, tergantung pada kualitas pendidik dan peserta didik, sumber daya dan efisiensi waktu yang ditentukan. Strategi pembelajaran terbalik ini juga cukup bagus untuk memperoleh pengetahuan secara prosedural. Dalam taksonomi Bloom yang telah direvisi oleh Lorin Anderson (1990), tujuan pembelajaran pada ranah kognitif terbagi menjadi 6 tingkatan, dimulai dari Remembering (mengingat), Understanding (memahami), Applying (menerapkan), Analyzing (menganalisis), Evaluating (mengevaluasi) dan Creating (menciptakan).

Untuk menerapkan strategi model flipped learning tersebut, tahapan mengingat (remembering) dan memahami (understanding) sebagai tingkatan ranah kognitif yang paling rendah, dilakukan di luar kelas. Sedangkan kegiatan pembelajaran peserta didik di ruang kelas lebih fokus pada empat tingkatan kognitif teratas, yaitu tahap applying, analyzing, evaluating dan creating (Zainuddin et al., 2016 : 315). Sebagai gambaran, para peserta didik disajikan berbagai konten materi dalam bentuk ceramah yang direkam maupun video yang diakses di luar kelas. Kemudian segala bentuk pengetahuan dan pemahaman materi melalui bacaan, audio-visual tersebut akan mengantarkan peserta didik kepada tingkatan kognitif yang lebih tinggi 
ketika berada di ruangan kelas. Berikut merupakan figur yang dapat menggambarkan strategi model flipped learning :

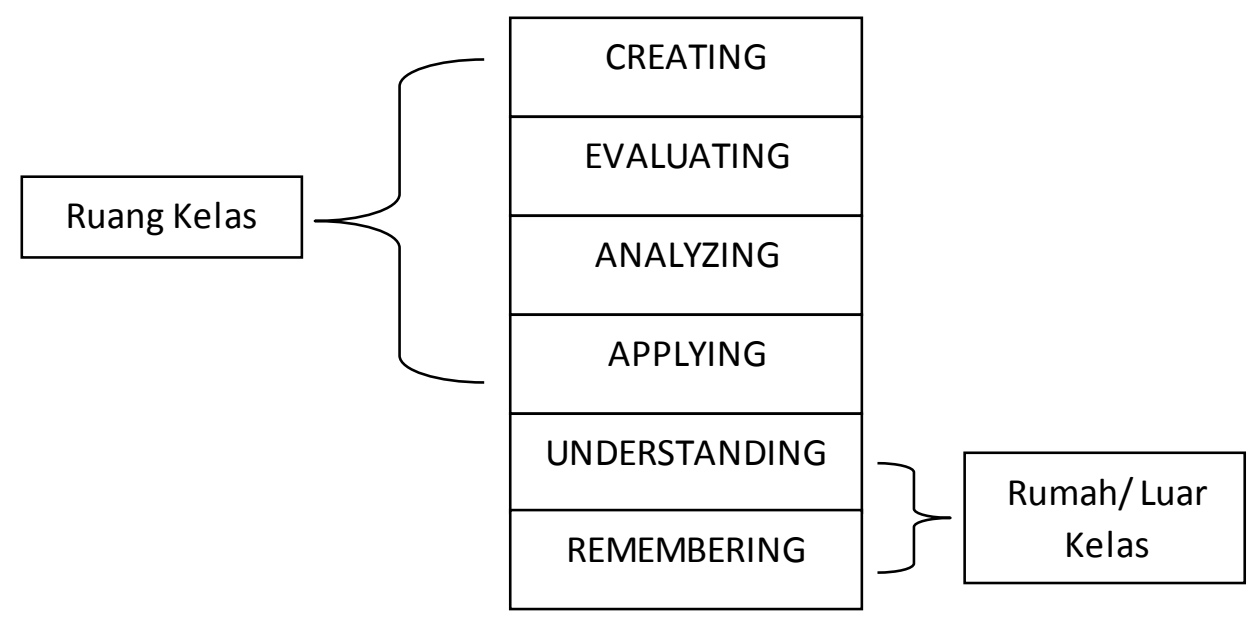

Figur 1 : Tabel Revisi Taksonomi Bloom dalam penerapan Flipped Learning

Dengan strategi model pembelajaran terbalik ini, peserta didik mampu mencapai tahap pengetahuan teratas dengan efisiensi waktu yang lebih banyak dihabiskan berdiskusi, bertukar gagasan, presentasi dan kegiatan belajar lainnya di ruangan kelas.

Secara teknis agar penerapan flipped learning berjalan dengan baik, para guru harus menyiapkan beberapa hal sebagaimana berikut :

a. Kemampuan melek teknologi atau TIK (Teknologi, Informasi dan Komunikasi) yang ada pada diri guru. Hal ini karena merekalah yang membuat konsep, mengatur panjang-pendek, banyak-sedikitnya materi yang diberikan kepada peserta didiknya. Atau setidaknya mereka lebih up-to-date menggunakan konten-konten video terkenal seperti YouTube dan sebagainya. Mereka tidak harus membacakan kitab klasik seperti pada umumnya dengan berceramah, melainkan juga dengan berkreasi melalui alat teknologi yang ada.

b. Media pembelajaran online seperti e-book, video, rekaman dan sebagainya

c. Perangkat teknologi yang memadai seperti komputer, laptop, handphone dan sebagainya 
d. Jaringan internet yang stabil. Hal ini menjadi penting jika seorang pendidik ingin menyiarkan video pembelajarannya secara live seperti video call, streaming dan sebagainya.

Dengan memperhatikan langkah-langkah tersebut, pendidik akan mudah mengimplementasikan pembelajaran model flipped learning. Pendidik juga mampu memanfaatkan teknologi dan informasi melalui pendekatan pedagogis tanpa menyita waktu peserta didiknya untuk mendengarkan ceramah dari awal hingga akhir proses belajar-mengajar. Di satu sisi, pendidik tersebut akan dapat menghemat tenaga, baik secara fisik maupun mental ketika mereka menghadapi peserta didiknya.

Implementasi model flipped learning di berbagai tingkatan pendidikan tentu menimbulkan beberapa kelebihan dan kekurangan. Hal tersebut dapat terjadi sebab tidak semua peserta didik memiliki motivasi belajar yang sama. Namun jika dilihat dari kebutuhan manusia terhadap teknologi saat ini, model flipped learning memiliki manfaat yang lebih besar terhadap kemandirian peserta didik daripada pembelajaran model konvensional pada umumnya. Menurut Roehling (2018), kelebihan utama flipped learning diantaranya adalah sebagai strategi yang lebih efektif bagi peserta didik untuk mencapai berbagai hasil belajar. Model flipped learning ini juga dapat meningkatkan kualitas pembelajaran peserta didik. Selain itu mereka juga dapat mengakses rekaman materi kapan saja, suasana pembelajaran di kelas menjadi lebih hidup, para pendidik menjadi lebih mudah menjangkau peserta didiknya melalui bimbingan langsung di kelas, dan yang paling penting, model pembelajaran kelas terbalik ini mampu menjadikan peserta didik memahami urgensi suatu teknologi dalam pembelajaran.

Millard (2012) menemukan 5 alasan positif mengapa flipped learning perlu dilaksanakan, diantaranya : (1) meningkatkan keterlibatan peserta didik dalam proses pembelajaran, (2) memperkuat keterampilan berbasis kinerja tim, (3) menawarkan pendekatan pendidik terhadap peserta didiknya secara personal melalui bimbingan/panduan, (4) aktivitas peserta didik seperti diskusi 
kelas menjadi lebih fokus, dan (5) peserta didik lebih bebas berkreasi (Schmidt \& Ralph, $2015: 3$ ).

Model flipped learning ini juga bermanfaat bagi para guru yang merasa jam mengajarnya kurang. Mereka merasa hal tersebut merupakan salah satu kendala dalam penyampaian materi. Karena kurangnya jam mengajar akan berimplikasi pada pembengkakan materi dan pada akhirnya pembelajaran tidak dapat dituntaskan dengan baik. Dengan flipped learning, pendidik lebih hemat waktu dalam penyampaian materi. Mereka hanya mendesain konsep dan membuat materi online, memberikan keywords dan menginstruksikannya kepada peserta didik dan kemudian menunggu hasil belajar mereka selama di luar kelas. Tugas yang diberikan akan diselesaikan secara mandiri oleh peserta didiknya. Selanjutnya di dalam kelas, mereka hanya menggunakan waktu dengan diskusi bersama, memandu kegiatan siswa dan sebagainya tanpa banyak menguras tenaga.

Model flipped learning ini memang tepat untuk peserta didik yang mampu memanfaatkan teknologi dan beradaptasi dengan konten-konten edukatif yang disajikan pendidiknya. Akan tetapi model ini tetap memiliki kekurangan jika diimplementasikan ke semua elemen yang terlibat, diantaranya :

a. Tidak semua pendidik atau peserta didik mempunyai alat teknologi untuk mengakses konten secara online. Sedangkan alat teknologi tersebut merupakan syarat mutlak yang harus ada dalam proses penerapan flipped learning.

b. Jika dikatakan semua pendidik atau peserta didik memiliki alat teknologi, namun hal itu tidak menjamin kelancaran proses pembelajaran flipped learning. Sebab kendala selanjutnya adalah tidak adanya kompetensi guru dalam TIK (Teknologi Informasi dan Komunikasi). Maka guru dituntut untuk melek teknologi untuk mengaksesnya.

c. Tidak semua peserta didik merasa nyaman belajar di depan alat teknologinya, seperti laptop atau komputer. Diantara mereka ada yang lebih suka membaca buku pelajaran, menulis secara manual dan gaya 
belajar lainnya selain menatap layar. Sedangkan komputer merupakan salah satu alat vital dalam pembelajaran flipped learning.

d. Model flipped learning menuntut kemandirian peserta didik melalui keywords atau gambaran singkat tentang materi yang akan dipelajarinya. Hal tersebut dapat menjadi kendala karena tidak semuanya mampu mencari dan menggali informasi secara mandiri. Adakalanya mereka membutuhkan motivasi gurunya sebelum menyampaikan materi di kelas, agar mereka lebih terbiasa.

e. Satu hal yang menjadi kunci utama keberhasilan model flipped learning adalah stabilitas jaringan internet. Tidak semua negara memiliki kekuatan jaringan yang kuat, termasuk negara Indonesia. Padahal fitur-fitur seperti live streaming, video call dan sebagainya membutuhkan koneksi cukup kuat. Maka proses pembelajaran akan terkendala dengan lemahnya koneksi jaringan internet, terutama dalam hal mengunduh suatu file konten yang cukup besar.

Menerapkan model flipped learning memang tidak mudah, khususnya pada PAI. Para instruktur harus memahami situasi dan kondisi yang akan dihadapinya. Apakah peserta didik sudah siap menerima konten materi berupa video, rekaman dan sebagainya untuk dipelajari di luar kelas? Apakah di rumah mereka sudah tersedia alat teknologi berikut jaringan yang memadai? Apakah orang tua atau orang terdekat siap mengawasi selama mereka mengakses konten secara intensif? Jika sudah demikian, maka pendidik dapat memulai pembelajaran terbalik dengan benar. Oleh karena itu selain memperhatikan langkah-langkah di atas, baiknya juga diadakan konsultasi antara pendidik, peserta didik dan orang tua. Karena semua elemen yang terlibat sangat mendukung pembelajaran flipped learning tersebut.

\section{Simpulan}

Model pembelajaran terbalik atau flipped learning merupakan salah satu inovasi dalam dunia pendidikan. Konsep yang dibangun adalah dengan mengalihkan pembelajaran langsung di ruang belajar berskala besar ke 
pembelajaran di ruang belajar yang lebih kecil atau individual. Pembelajaran terbalik ini mengubah pembelajaran bersifat teacher-centered menjadi student-centered. Artinya peserta didik menjadi lebih aktif dan lebih terlibat di ruangan kelas, dibandingkan dengan model konvensional yang cenderung menjadikan mereka pasif.

Guru sebagai instruktur menginstruksikan materi yang harus dipelajari siswanya dengan membuat konten materi berupa video, rekaman ceramah dan sebagainya yang diunggah ke layanan situs online. Di rumah atau di luar kelas, peserta didik harus bertanggungjawab untuk belajar secara mandiri melalui video atau rekaman ceramah tersebut. Selanjutnya mereka mempresentasikan dan mendiskusikannya di dalam kelas secara kolaboratif. Maka pembelajaran model flipped learning ini termasuk konsep blended learning yang memadukan pertemuan tatap muka di dalam kelas dan belajar mandiri di luar kelas.

Penerapan model flipped learning pada pembelajaran PAI akan terasa mudah jika para elemen yang terlibat telah memiliki fasilitas yang memadai, seperti kompetensi TIK (Teknologi Informasi dan Komunikasi), jaringan internet yang stabil, mental peserta didik dalam belajar, kemandirian belajar dan sebagainya. Jika tidak, maka pembelajaran terbalik akan sulit diterapkan. Karena flipped learning sangat erat kaitannya dengan teknologi, terutama di pembelajaran abad 21 ini. 


\section{Daftar Pustaka}

Hamdan, Noora., McKnight, Patrick., McKnight, Katherine., \& Arfstrom, Kari. M. A Review of Flipped Learning. Arlington, VA: Flipped Learning Netwoks, 2013.

Herreid, Clyde F. \& Schiller, Nancy. "Case Studies and the Flipped Classroom". Journal of College Science Teaching, Vol. 42, No. 5 (Mei, 2013).

https://esaiedukasi.com/2019/02/kontroversi-metode-flipped-classroom.html

https://flippedlearning.org/

http://.maria-paristio wati.com/2016/05/flipped-classroom-sebuah-alternatif.html

http://rinapermatasari15.blogspot.com/2014/09/flipped- learning.html

Hu, Fang, dkk. " A Flipped Classroom Designed for the Teaching of Network Equipment Configuration and Management". Open Journal of Social Sciences, Vol. 7, No. 5 (Mei, 2019), 201-2018. DOI : https://doi.org/10.4236/jss.2019.75016.

Huxham, Mark. "Learning in Lectures : Do 'interactive windows' help?". Active Learning in Higher Education Journal, Vol. 6, No. 1 (Maret, 2005), 17-31. DOI : https://doi.org/10.1177/1469787405049943.

King, Alison. "From Sage on the Stage to Guide on the Side". College Teaching Journal, Vol. 41, No. 1 (Juli, 2010), 30-35. DOI : http//dx.doi.org/10.1080/87567555.1993.9926781.

Krathwohl, David R. "A Revision of Bloom's Taxonomy: An Overview". Journal of Theory Into Practice, Vol. 41, No. 4 (2002), 212-218. DOI : https://doi.org/10.1207/s15430421tip4104_2.

Nouri, Jalal. "The Flipped Classroom: For Active, Effective and Increased Learning - Especially For Low Achievers". International Journal of Educational Technology in Higher Education, Vol. 13, No. 33 (Agustus, 2016), 1-10. DOI : https//doi.org/10.1186/s41239-016-0032-z.

Roehling, Patricia V. Introduction to Flipped Learning : the first side of the book titled : Flipping The College Classroom. Cham: Palgrave Pivot, 2018.

Sams, Aaron \& Bergmann, Jonathan. Flip Your Classroom : Reach Every Student in Every Class Every Day. Washington DC : ASCD, 2012.

Schmidt, Stacy M. \& Ralph, David L. "The Flipped Classroom : A Twist on Teaching",Contemporary Issues in Education Research, Vol. 9, No. 1 (2016) 
1-6. DOI : https://doi.org/10.19030/cier.v9i1.9544.

Whitmann Cobb, Wendy N. 'Turning the Classroom Upside Down: Experimenting With The Flipped Classroom in American Government". Journal of Political Science Education, Vol. 12, No. 1 (September, 2014), 114. DOI : http://dx.doi.org/10.1080/15512169.2015.1063437.

Zainuddin, Zamzami \& Halili, Siti Hajar. "Flipped Classroom Research and Trends from Different Fields of Study". International Review of Research in Open and Distributed Learning Journal, Vol. 17, No. 3 (April, 2016), 313340. DOI : https:/doi.org/10.19173/irrodl.v17i3.2274.

Zed, Mestika. Metode Penelitian Kepustakaan. Jakarta: Yayasan Obor Indonesia, 2004. 